\title{
ОЦЕНКА ЭФФЕКТИВНОСТИ ОБУЧЕНИЯ В ШКОЛЕ ДИАБЕТА ДЕТЕЙ ПОДРОСТКОВОГО ВОЗРАСТА С САХАРНЫМ ДИАБЕТОМ 1 ТИПА
}

\author{
И.Л. Алимова, А.Н. Демяненко \\ ФГБОУВО «Смоленский государственный медицинский университет» МЗ РФ, Смоленск, \\ Российская Федерачия
}

\begin{abstract}
ЦЕЛЬ - оценить эффективность обучения в школе диабета детей подросткового возраста с сахарным диабетом 1 типа (СД1) для повышения качества обучения.

МАТЕРИАЛЫ И МЕТОДЫ. Обследовано 33 пациента С СД1 в возрасте 10-17 лет (14,5 года $[12,0-16,0])$ с диагнозом СД1, длительностью заболевания 1,5-15 года (5,0 лет [3,0-6,0]), уровнем гликированного гемоглобина $\left(\mathrm{HbA}_{1 c}\right)$ от 6,4 до $11,7 \%(8,7 \%[7,8-10,1])$ и находящихся на базисно-болюсной инсулинотерапии. Всем пациентам проводилось анкетирование для оценки эффективности прохождения пациентами Школы Диабета по проведению самоконтроля заболевания. В анкету было включено 11 вопросов по инсулинотерапии, 10 вопросов по питанию, 8 вопросов по контролю гликемии и 4 вопроса по физической нагрузке. Также проводилась оценка качества жизни (КЖ) с помощью опросника PedsQL ${ }^{\mathrm{TM}} 4.0$ (диабетического модуля). Статистическая обработка проводилась с помощью программы Statistica 7.0 (StatSoft 2009).
\end{abstract}

РЕЗУЛЬТАТЫ. Среди опрошенных пациентов у 11 (33\%) были диагностированы хронические осложнения диабета (полинейропатия, нефропатия, хайропатия), у 8 (24\%) - синдром нарушенного распознавания гипогликемии (по Clarke). Лишь у 4 (12\%) HbА был $<7 \%$. При анализе анкеты вопросов Школы диабета процент правильных ответов по всем блокам составил 56,6\% [27,2; $84,8]$. Процент правильных ответов по вопросам инсулинотерапии $(58,6 \%[36 ; 100])$ был сопоставим с результатами по вопросам питания $(50 \%[20,0 ; 80,0]))$, контроля углеводного обмена $(53,5 \%[25,0 ; 87,5] ;$ p >0,05). Низкий процент правильных ответов был получен по вопросам клиники и купирования неотложных состояний - кетоацидоза (10 (34,5\%)) и гипогликемии (15 (51,7\%)), технике инъекций инсулина - 8 (27,6\%). Средний результат правильных ответов по блоку вопросов по физической нагрузке составил 74\% [50; 100$]$ при низкой доле правильных ответов на вопрос о контроле показателей гликемии при занятиях физической нагрузкой - 8 (27,6\%).

При оценке качества жизни (КЖ) максимальный балл был получен по шкале «общение» (92 [75; 100]) в сравнении со шкалами «диабет» (64 [54; 75]), «лечение» (80 [68; 91]), «беспокойство» $(67[50 ; 83])(p=0,035)$. Общий балл при оценке КЖ составил 73 [60;84]. При проведении корреляционного анализа установлена прямая взаимосвязь между процентом правильных ответов по анкете Школы диабета и баллами опросника КЖ по шкалам «диабет» $(r=+0,65 ; p=0,025)$, «лечение» $(r=+0,70 ; p=0,031)$, а также общим баллом $(r=+0,67 ; p=0,034)$.

Таким образом, полученные результаты показали необходимость построения индивидуальных программ повторного обучения подростков с СД1 в Школе диабета с учетом результатов предварительного анкетирования. 